\title{
DISTRIBUTION AND COMMUNITIES OF CRYPSIS ACULEATA AND HELEOCHLOA SCHOENOIDES IN SLOVAKIA
}

\author{
Pavol ELIÁŠ jun.*, Daniel DÍTĚ**, Vít GRULICH*** \& Marek SÁDOVSKÝ****
}

\begin{abstract}
The distribution and communities of two annual grasses Crypsis aculeata and Heleochloa schoenoides were studied in Slovakia during 2003-2007. Herbarium and field data were used to reconstruct the occurrence of both taxa. A strong decline in C. aculeata localities was observed. This was mainly due to the destruction of periodically flooded saline habitats. By contrast, the occurrence of $H$. schenoides was changed only slightly. This species survives in secondary habitats (rural roads, field margins, field depressions). Point maps of historical and recent distribution are presented. Halophile vegetation of Crypsis aculeata and Heleochloa schoenoides has been sampled with the adapted Braun-Blanquet method. All collected relevés have been classified using the JUICE software. The results showed that the Crypsidetum aculeate Wenzl 1934 community is missing now in Slovakia, but Heleochloetum schoenoidis (Soó 1933) Țopa 1939 was still recorded at a few sites. However, the community contained many ruderal plant species.

Key words: Crypsis aculeata, Heleochloa schoenoides, halophytes, saline soils, distribution, vegetation, Slovakia

Izvleček

Raziskave razširjenosti dveh enoletnih trav Crypsis aculeata in Heleochloa schoenoides smo raziskovali na Slovaškem med letoma 2003 in 2007. Za rekonstrukcijo pojavljanja obeh vrst smo uporabili herbarijske in terenske podatke. Opazili smo močno upadanje števila nahajališč, kjer se pojavlja C. aculeata. Razlog je predvsem uničenje periodično poplavljenih slanih rastišč. Nasprotno pa se je pojavljanje vrste H. schenoides le malo spremenilo. Vrsta lahko uspeva tudi na sekundarnih rastiščih (kolovozi, robovi njiv, uleknine na njivah). Historično in recentno razširjenost smo prikazali na točkovnih kartah. Halofilno vegetacijo vrst Crypsis aculeata in Heleochloa schoenoides smo vzorčili s prilagojeno Braun-Blanquetovo metodo. Vse popisno gradivo smo klasificirali s programom JUICE. Rezultati so pokazali, da asociacije Crypsidetum aculeate Wenzl 1934 na Slovaškem ne najdemo več, medtem ko je bila asociacija Heleochloetum schoenoidis (Soó 1933) Țopa 1939 najdena na nekaj rastiščih, vendar se v njej pojavljajo številne ruderalne rastlinske vrste.
\end{abstract}

Ključne besede: Crypsis aculeata, Heleochloa schoenoides, halofiti, slana tla, razširjenost, vegetacija, Slovaška

\section{INTRODUCTION}

Saline soils belong to hydromorphic soils which are strongly influenced by intensive water evaporation, and the salt dynamics of ground water is the most important factor in their formation. The saline soils contain toxic concentrations of soluble salts in the root zone. The soluble salts consist of chlorides and sulphates of sodium, calcium and magnesium (Buol et al. 1997, Boros 2003). Areas

\footnotetext{
* Department of Botany, Slovak University of Agriculture, Tr. A. Hlinku 2, SK-949 76 Nitra, Slovakia, pelias@afnet. uniag.sk

** Institute of Botany, Slovak Academy of Sciences, Dúbravská cesta 14, SK-84523, Bratislava, Slovakia, daniel.dite@ savba.sk

*** Department of Botany and Zoology, Masaryk University, Kotlářská 2, CZ-611 37 Brno, Czech Republic, grulich@ sci.muni.cz

**** Nábrežná 8, SK-941 03 Úl’any nad Žitavou, Slovakia, msadovsky@gmail.sk
} 
of saline soils are widely distributed over the world and constitute approximately $10 \%$ of the terrestrial surface (Szabolcz 1991, O’Leary \& Glenn 1994). In Central Europaean countries with an arid continental climate, saline soils are widely spread mainly throughout Hungary, where alkali habitats cover nearly 400000 ha (Molnár \& Vajda 2000).

In Slovakia, saline soils covered by halophytic plant communities are distributed mainly in warm and dry lowland regions. The largest areas of saline soils are concentrated in the Danube Lowland - they are distributed from the surroundings of towns of Komárno and Štúrovo to the town of Nitra (Krist 1940, Krippelová 1965). The second area of saline soils is in the East Slovakian Lowland in the neighbourhood of the villages of Malčice, Zemplínske Kopčany, Malé Raškovce, and Vel'ké Raškovce (Vicherek 1964). The last small area near the town of Malacky in the Záhorská nížina Lowland (Krist 1940) was destroyed in the sixties. Saline soils created by the mineral springs in basins of northern Slovakian mountains represent special habitats (ك̌marda 1961, Vicherek 1973, Dítě \& al. 2004).

The areas of saline soils have all been markedly reduced during the last few decades due to human activities. For instance, Osvačilová \& Svobodová (1961) mentioned approximately 8300 ha of soil with saline vegetation in the Danube Lowland, but today only 500 ha have been re-discovered there (Sádovský \& al. 2004b). It is this reduction that strongly affects these plant communities distributed on soils with high salinity and a high level of underground water level during spring months. For example, we confirmed that Camphorosmetum annuae now covers only a few square metres in Slovakia, but the typical vegetation was found only at some of the last square decimetres. Initial stages of periodically flooded saline soils are now rare and are usually developed in secondary biotopes (fields and field borders, depressions in rural roads etc.).

Plant communities of periodically flooded saline habitats represent unique initial stages of plant succession. They cover river banks as well as terrain depressions. The formation of these plant communities is closely associated with annual water level decrease and we can usually find it in the second half of the vegetation period. This type of biotope is rare in Slovakia nowadays; it has predominantly developed in wet depressions of intensively farmed fields. Vegetation of saline flooded banks is even more seldom - only two micro-localities still exist (Sádovský \& al. 2004a).
Typical dominants of periodically flooded saline soils are annual grasses Crypsis aculeata (L.) Aiton and Heleochloa schoenoides (L.) Host ex Roem. Crypsis aculeata occupies a wide area from North Africa, Spain and Portugal to northern China and Mongolia. Distribution of Heleochloa schoenoides is very similar. However, the area of the species gets larger towards Tibet and northwestern India; in Africa from Senegal to Mozambique, Malawi, Tanzania, and Madagascar (Conert 1983). The northern distribution border of both species passes through Central Europe (Holub \& Grulich 1999a, b), occurrence of these species in this region has always been rare. The situation of historical and present occurence in the Czech Republic was described by Grulich (1987). Both species are evaluated as critically endangered in Slovakia (Feráková \& al. 2001) and the Czech Republic (Holub \& Procházka 2000). In Austria, Crypsis acuelata is evaluated as endangered, while Heleochloa schoenoides as strongly endangered (Niklfeld \& Schratt-Ehrendorfer 1999).

Crypsis acuelata and Heleochloa schoenoides plant communities are usually included in classis Crypsidetea aculeatae Vicherek 1973, ordo Crypsidetalia aculeatae Vicherek 1973 and alliance Cypero-Spergularion salinae Slavnić 1948. Within the frame of this alliance both taxa are components of some associations and subassociations (see Vicherek 1973, Mucina \& Maglocký 1985, Mucina 1993, Borhidi 1996, Pop 2002 etc.).

\section{The aims of our paper were:}

a) to describe the historical and recent distribution of Crypsis aculeata and Heleochloa schoenoides in Slovakia,

b) to assess the recent stage of initial Crypsis aculeat $a$ and Heleochloa schoenoides saline communities in Slovakia,

c) to compare present vegetation data with older works published by Krist (1940) and Vicherek (1973).

\section{MATERIAL AND METHODS}

The study was carried out during the years 20032007. The data concerning the distribution of the species were obtained from herbariums BP, BRA, BRNU, BRNM, NI, NIM, KO, MMI, PMK, PR, PRC, SAV, SLO and ZV. Herbarium specimens collected during field research are stored in herbarium 


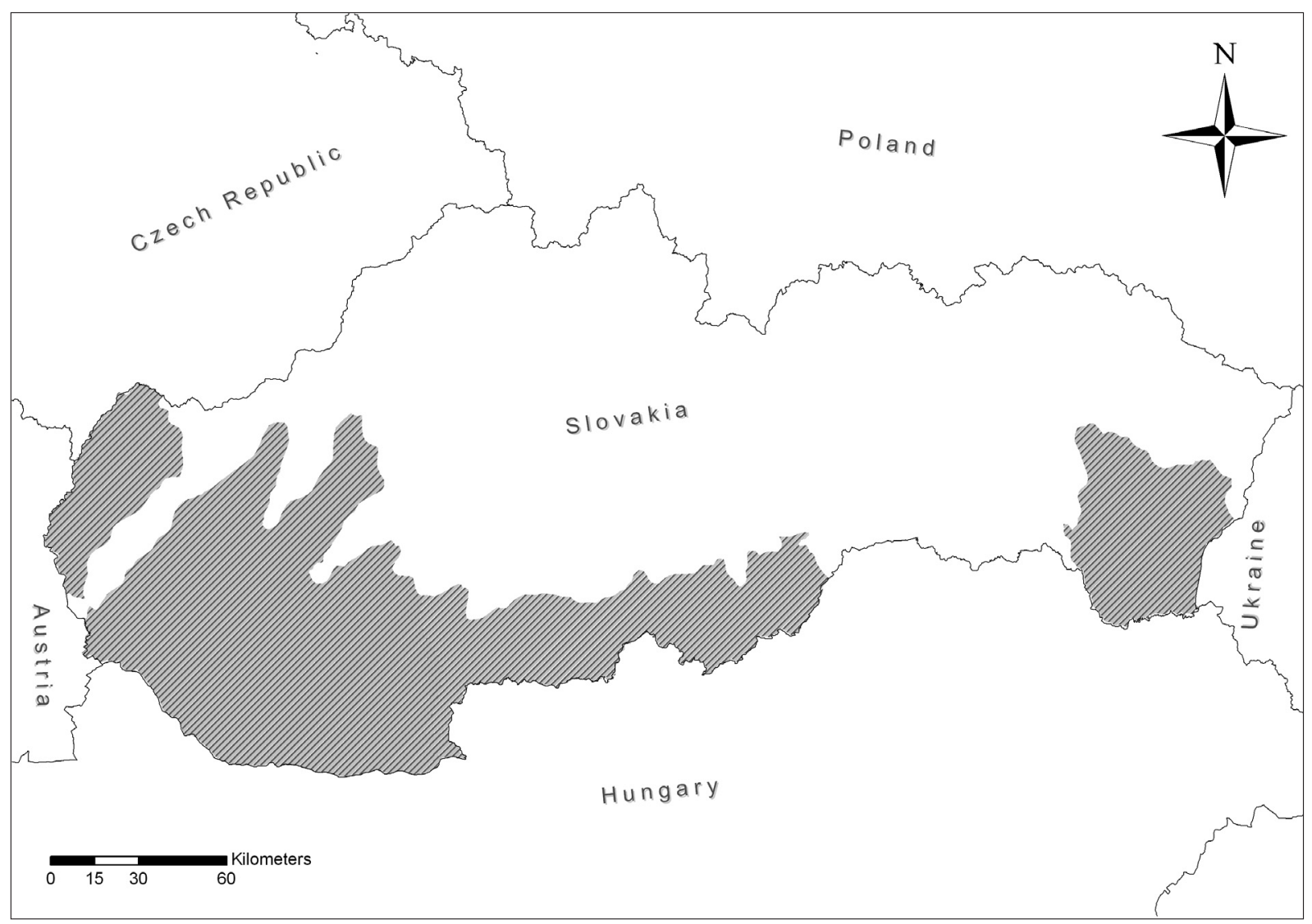

Figure 1: Area of study.

Slika 1: Območje raziskav.

NI. Herbarium abbreviations are used according to Holmgren \& al. (1990) and Vozárová \& Sutorý (2001). The active field research was carried out to confirm recent localities of these species. Results of this study are presented on the point maps constructed using DMAP software. The grid on the maps $\left(5^{\prime} \times 3\right.$ ') follows one that was described by Niklfeld (1971).

The vegetation relevés were sampled according to the Zürich-Montpellier approach using the adapted Braun-Blanquet scale (Barkman \& al. 1964). All relevés were stored using the TURBOVEG database software (Hennekens \& Schaminée 2001) and data analyzed in JUICE software (Tichý 2002).

The nomenclature of ferns and flowering plants follows Marhold \& Hindák (1998), the names of syntaxa are used in accordance with Molnár \& Borhidi (2003). The abbreviations of works published before 1956 follows Futák \& Domin (1960). Phytogeographical divisions of Futák (1980) are also used (Fig. 1).

\section{RESULTS AND DISCUSSION}

\subsection{Distribution of Crypsis aculeata (L.) Aiton in Slovakia}

The species is distributed only on the Danube Lowland in Slovakia. In the course of our study we found all together 30 localities of Crypsis aculeata. Half of them were documented by herbarium specimens, the other part was mentioned only in the literature (see Fig. 2 and data below). However, we would here like to refer to frequent determination mistakes - young individuals of Heleochloa schoenoides were often determined as Crypsis aculeata. Hence we take it that approximately a third of all the literature data are probably erroneous and therefore they need to be used with care. Our deduction is based on the fact that C. aculeata is an obligate halophyte and it grows only on strongly salinizated soils of saline lakefronts (Krist 1940). On the other hand, Heleochloa schoenoides, although included in 
the group of obligate halophytes (Krist 1940) colonizes even more dry sub-saline and ruderal habitats (field depressions, rural roads, fallows etc.). Sádovský \& al. (2004a) interpreted it as an effect of a wider ecological amplitude of $H$. schoenoides.

Novák (1954) also mentioned the species from saline biotopes of the Záhorská nížina lowland, but he did not point out any exact site. We consider this record doubtful.

We established a marked reduction of Crypsis aculeata distribution (Fig. 2.) with respect to strong changes in Slovak saline areas (see Sádovský \& al. 2004b). The species occurs now only at two microsites in the village of Trrdošovce. We ascertained during our field research that all other localities were destroyed - predominantly by land reclamation (Búč, Dolný Jatov, Hájske, Močenok, Nový Život, Palárikovo, Śurany, Trnovec nad Váhom, Vel'ká Dolina, Zlatná na Ostrove), but also by building development (Komárno, Malá Maňa) and forestation by hybrid poplars (Vel'ké Kosihy).

A specimen of Crypsis aculeata collected by Samuel Kupčok was found in the herbarium BP. The specimen's label mentioned the village of Pukanec (the Štiavnické vrchy Mts. in the Carpaticum phytogeographical region). We assumed that this specimen probably had its label accidentally exchanged, because no saline habitats exist in this region (neither presently nor historically) and Kupčok did not include this species in his review of Pukanec flora (Kupčok 1956).

\subsection{Distribution of Heleochloa schoenoides (L.) Host ex Roemer in Slovakia}

The occurrence of Heleochloa schoenoides is concentrated in the southwestern and southeastern part of Slovakia. Most of the 30 localities are known from the territory of the Danube Lowland, but one locality was reported from a lower reach of the river of Ipel' (Zalaba) and circa 10 locations were found in the East Slovakian Lowland (Fig. 3).

Novák (1954) mentioned the occurrence of this species in the Záhorská nížina Lowland. However, the origin of this reference is not clear. Similarly as in the case of Crypsis aculeata, we found no other literature reference or herbarium specimen of Heleochloa schoenoides from this region. However, a recent occurrence of Heleochloa schoenoides on the sand bank of the Dyje River (near the junction with the Morava River) was published in South Moravia (Šumberová et al. 2000). A recent occurence is also known from the Austrian part of Marchfeld

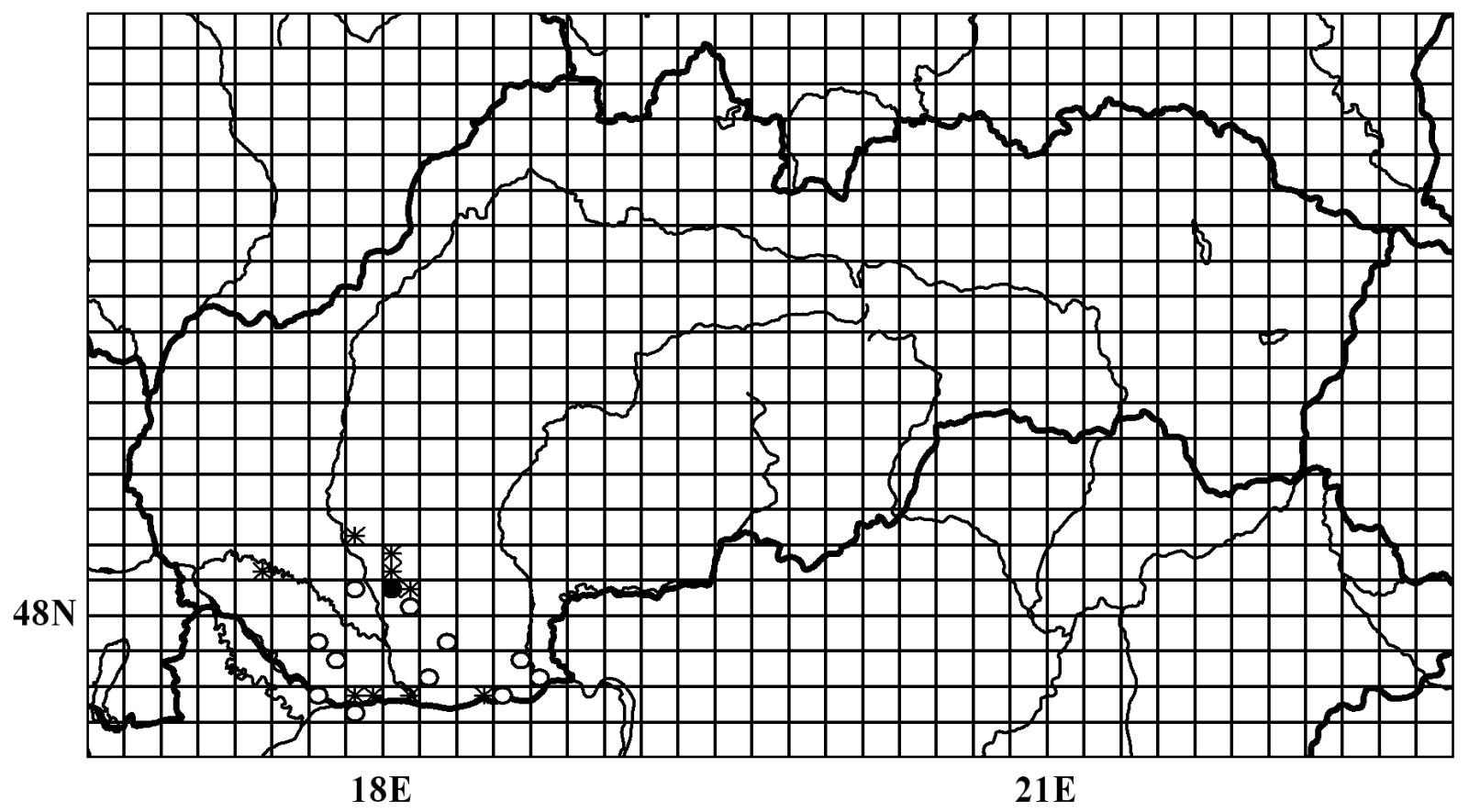

Figure 2: Historical and recent distribution of Crypsis aculeata in Slovakia: * - data from literature, $\circ$ - before $1980, \bullet-1980$ onwards.

Slika 2: Historična in recentna razširjenost vrste Crypsis aculeata na Slovaškem: * - literaturni podatki, ○ - pred 1980, - po 1980 . 


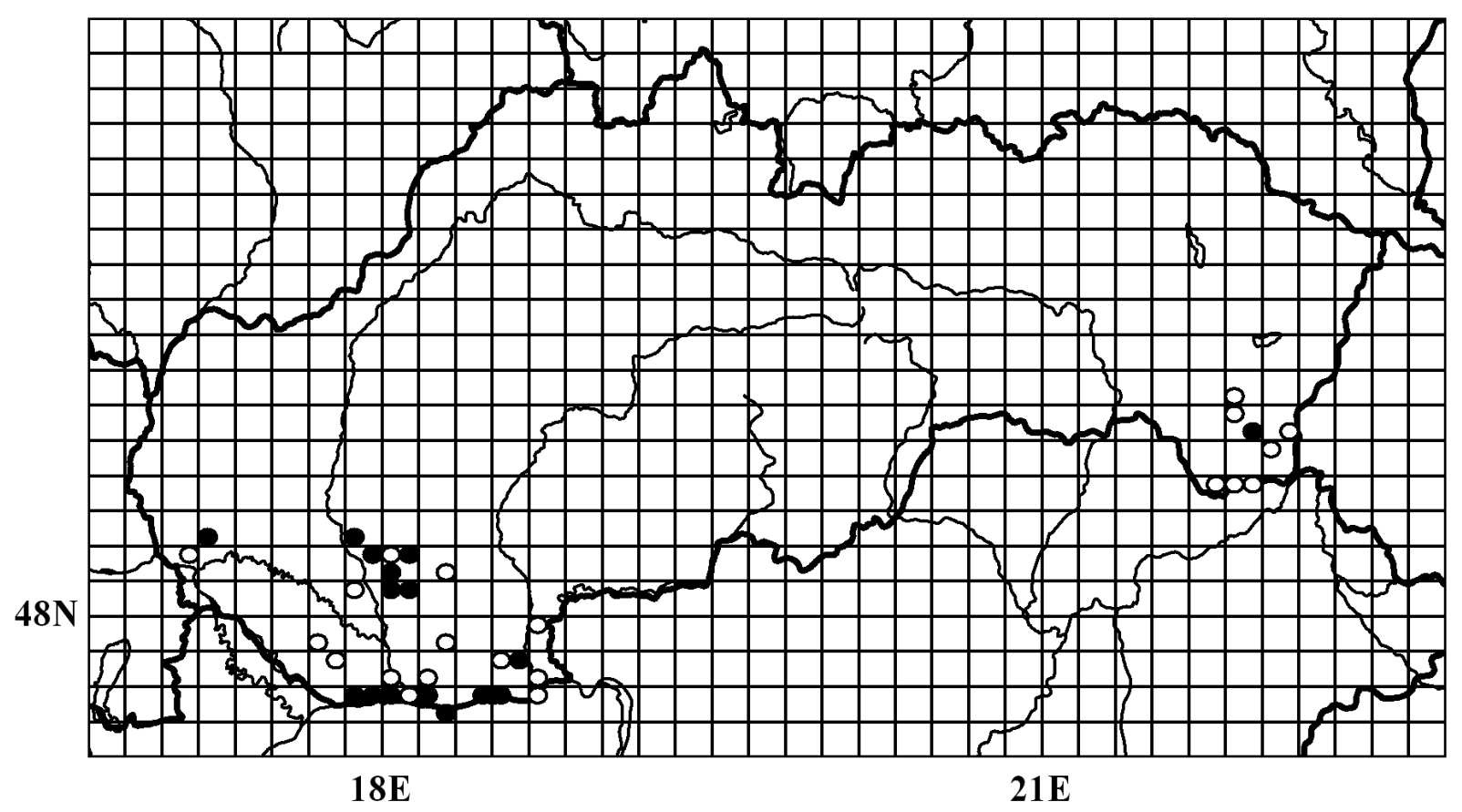

Figure 3: Historical and recent distribution of Heleochloa schoenoides in Slovakia: ○ - before 1980, • 1980 onwards. Slika 3: Historična in recentna razširjenost vrste Heleochloa schoenoides na Slovaškem: o - pred 1980, • po 1980.

(Schratt-Ehrendorfer 1999). These findings evoke an idea of the species possibly occurring on the Záhorská Lowland in Slovakia as well.

Heleochloa schoenoides hybridizes with its sibling species $H$. alopecuroides. Both species grow in similar ecological conditions and are often found together. The hybrid - Heleochloa $\times$ bernatskyana (Degen) Boros - was reported from the surroundings of the Mužla Village. The specimen is deposited in the herbarium in Budapest (Boros 1917 BP). This hybrid needs further study: it is not clear if the cited specimen represents a real hybrid combination or only an extreme variability of one of the supposed parents.

Recent distribution of the species more or less corresponds to pre-existent localities. Contrary to previous species, Heleochloa schoenoides is adapted to the strong disturbance of saline habitats (amelioration, ploughing) and it also frequently colonizes secondary sites. We found the species at 18 localities on the Danube Lowland. We did not confirm its occurrence on the East Slovakian Lowland. On the other hand, Zlacká (2006) confirmed one locality in East Slovakia in 2005 and many localities were found here earlier in the past (Vicherek 1964). On the basis of these data, we now assume a more frequent occurrence of $H$. schoenoides in the area.
Many plant species of denuded beds (e. g. Carex bohemica, Dichostylis micheliana, Schoenoplectus supinus etc.) occur irregularly - in years with favourable climatic conditions they create large populations but in years of unfavourable climatic conditions they are missing (Hejný 1960, Holub 1999).

\subsection{Communities with dominance of Crypsis aculeata in Slovakia}

We found a biotope of periodically flooded saline banks with the presence of Crypsis aculeata only at two microlocalities during our study. Both were situated in the urban area of Tvrdošovce village (Fig. 4).

Vegetation on flooded lakesides fluctuated distinctively from year to year depending on the water levels of the two lakes mentioned above. A high abundance of vascular plants was observed during the relatively dry and warm years of 2003 and 2004. By contrast in years 2005-2006 the water level was relatively stable and no contiguous plant cover was discovered. Abundance of Crypsis aculeata was always rather low in those two habitats - the species covered only 5-50\% area of the relevés, usually $10-25 \%$. The number of all species recorded 


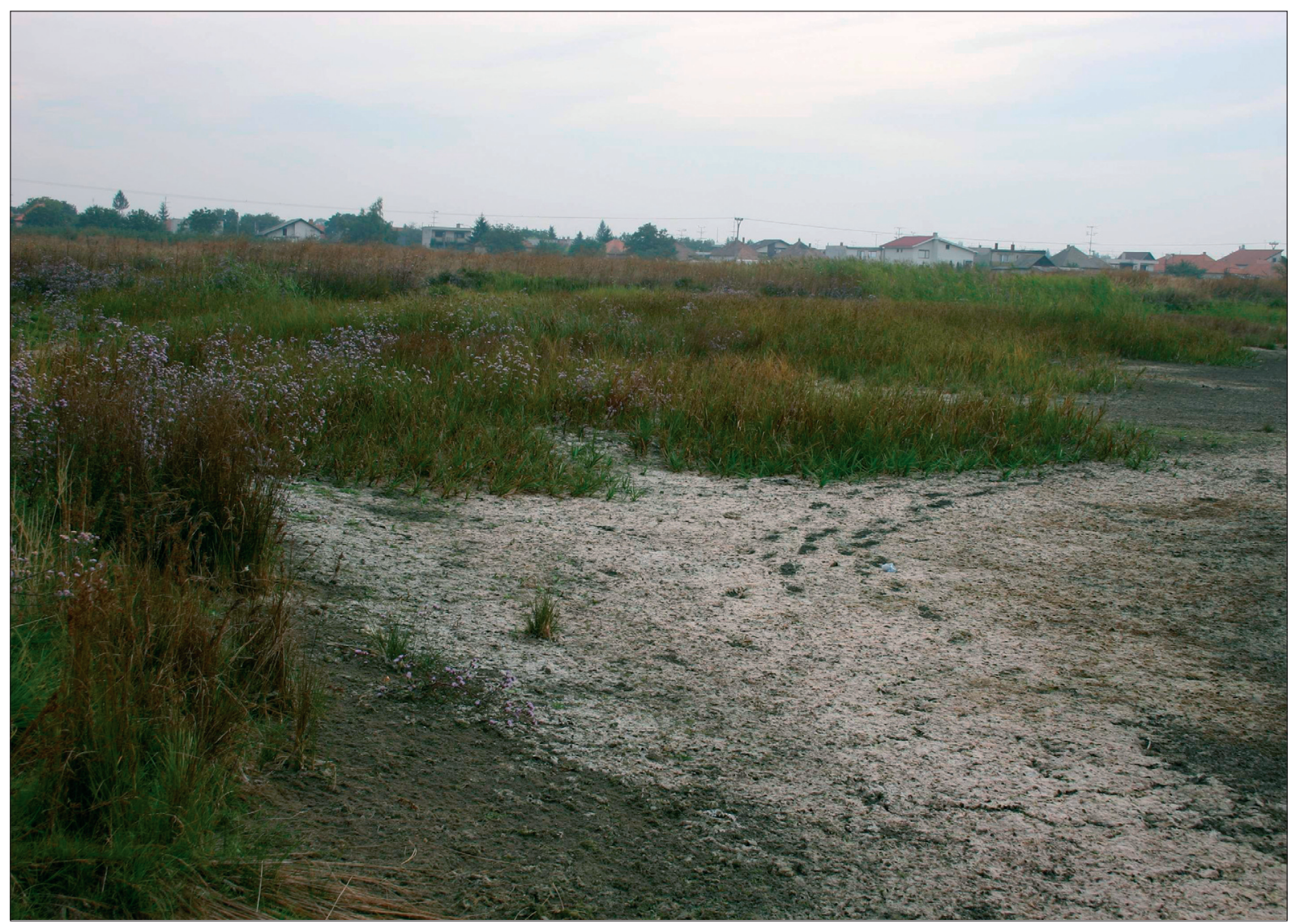

Figure 4: Village of Tvrdošovce: one of two last microsites of Crypsis aculeata in Slovakia. Denuded waterbanks of the small pool are in optimal conditions covered by an ephemeral community with presence of this species. Photo: D. Dítě, 21. 9. 2004.

Slika 4: Pri vasi Tvrdošovce: eno od dveh zadnjih mikrorastišč vrste Crypsis aculeata na Slovaškem. Goli bregovi manjših mlak so v najugodnejših razmerah porasli z efemerno združbo te vrste. Foto: D. Dítě, 21. 9. 2004.

per plot was also relatively low. The species richness varied from 6 to 16 species per relevé (average 9.8). On the basis of these data we classified both communities as association Heleochloetum schoenoidis (Soó 1933) Țopa 1939 [syn. Cyripsidetum schoenoidis (Soó 1938) Țopa 1939]. It must be noted that this vegetation was also strongly ruderalized (Table 1 , relevés no. 3-10).

We found that the recent conditions are not optimal for the existence of Crypsidetum aculeatae at the two above mentioned microlocalities in the area of Tvrdošovce village (and in the whole of Slovakia respectively). We therefore suppose that this plant community is now missing in Slovakia. The last occurrence of Crypsidetum aculeatae in Slovakia was thus confirmed by Valachovič (1995) in the same village in the first half of the nineties. It is interesting that the author did not mention Heleochloa schoenoides in his relevés, since we found Crypsis aculeata always together with $H$. schoenoides there. This change could be a result of desalination of the soil.

By comparing our data with the work of $\mathrm{Vi}$ cherek (1973) from the former Czechoslovakia, the correctness of our conclusions that the studied vegetation is now missing in Slovakia can be clearly confirmed. The author differentiated two subassociations within the scope of Crypsidetum aculeatae using data from South Moravia and south-west Slovakia. Subassociation typicum Vicherek 1973 is characterised by strong dominance of Crypsis aculeata species (over $75 \%$ ) and the very low number of other taxa per relevé (3-6 species). Subassociation chenopodietosum glauci Bojko ex Vicherek 1973 was distinguished based on the dominance of Chenopodium glaucum (abundance 75-100 \%) and Spergularia salina (up to $50 \%$ ). By contrast Crypsis aculeata was present only sparsely, the author mentioned maximal abundance up to $25 \%$. The number of species per relevé was low again (3-7 species). 


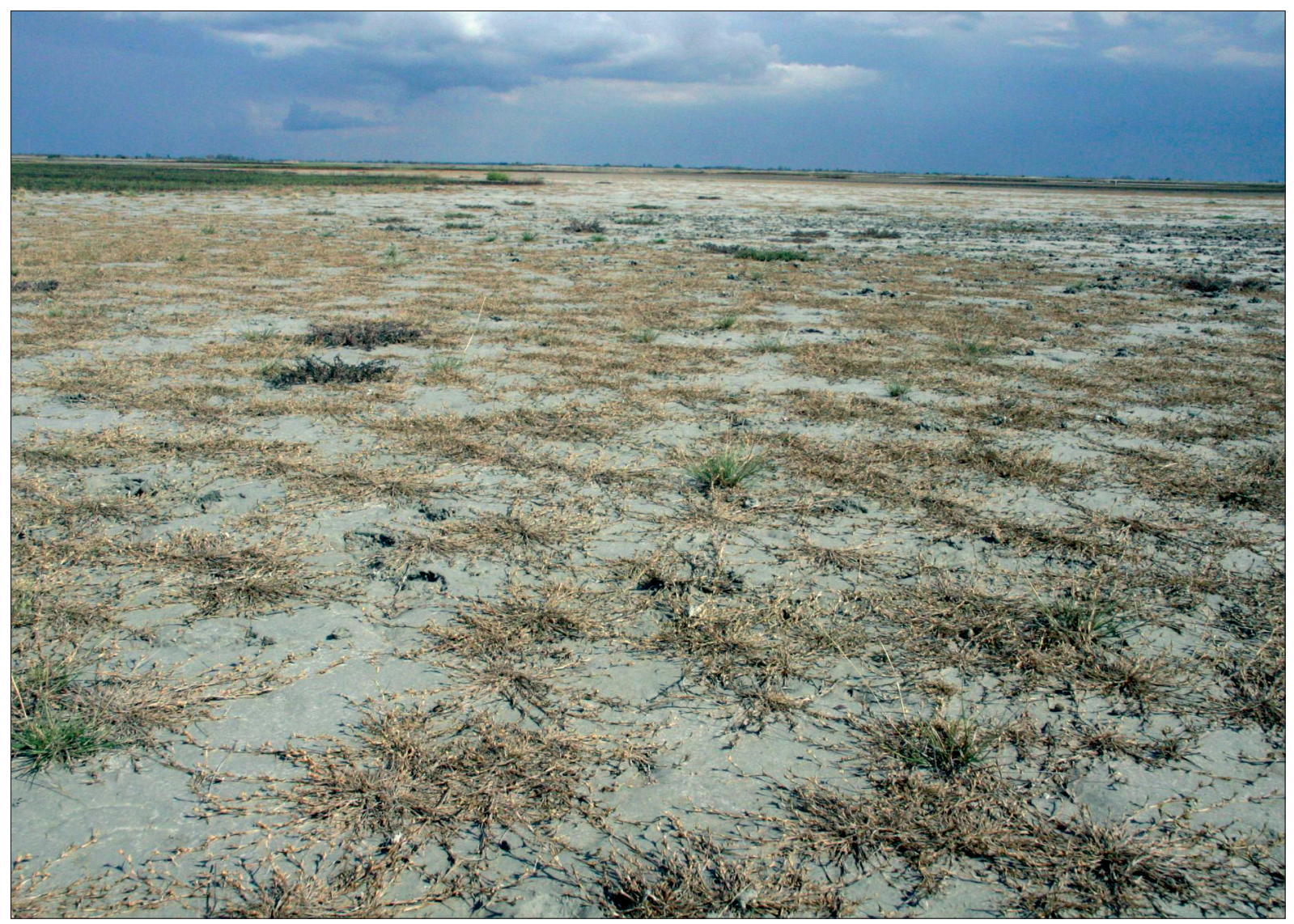

Figure 5: The Kelemen-Szék Lake in Hungary, typical association of Crypsidetum aculeatae on denuded saline bank. Photo: D. Dítě, 11. 9. 2007.

Slika 5: Jezero Kelemen-Szék Lake na Madžarskem, tipična asociacija Crypsidetum aculeatae na golih slanih brežinah. Foto: D. Dítě, 11. 9. 2007.

Vicherek (1973) regarded Crypsidetum aculeatae as a Pontic-pannonian community. Outside Slovakia, the association was reported from northeastern Austria (Bojko 1931, 1932, Wendelberger 1959), southeastern part of the Czech Republic (Vicherek 1962, 1973, Sumberová 2007), central and eastern Hungary (Soó 1934, Timár 1954, Borhidi 1996, Molnár \& Borhidi 2003), northern part of Serbia (Slavnić 1948, Kojić et al. 1998), Romania (Țopa 1939, Sanda et al. 1999, Popescu 2005a) and Ukraine (Bilik 1937, 1963). Hilbig (2000) mentioned the community from Mongolia which was the reason why Šumberová (2007) assumed occurrence of the association on salt steppes in southern Russia. On the other hand, Mucina (1993) mentioned the community only from Austria, the Czech Republic, Slovakia, Hungary, and Serbia. In addition to that, Micevski (1965) described a Macedonian endemic community Crypsidetum aculeatae balcanicum, which was developed in small depres- sions and channels in Ovče Pole. The author described this community on the basis of the occurrence of species Puccinelia convoluta and Spergularia marginata which are not present in Crypsidetum aculeatae described from Central Europe. Revision of his data is needed in the future.

A survey of the saline lakes in Central Hungary (surroundings of the villages of Akasztó, Fülopszálás, Harta and Solt) was made in 2006 and 2007 to obtain comparative data of vegetation with Crypsis aculeata. We found a typical cover of the species comparable to data given by Timár (1954), Wendelberger (1959) and Vicherek (1973) (Tab. 2). We recorded a wide area of dry saline lakes overgrown by thousands of individuals of the species (Fig. 5). On the other hand, it seems that this community is abundant only locally in Hungary, because Varga \& Várgáné (1999a) included it in the Red book of Hungarian vegetation. Similarly, the community is sporadic in Austria - it occurs only in the area of 
the Neusiedler See (Mucina 1993, Körner 2006). In Serbia Crypsidetum aculeatae is rare and occurs mainly in northern Serbia (Vojvodina: Potamišje, Derečka bara). Only a few isolated sites are found in southern parts of the country in the surroundings of the Bujanovac settlement (Vučković 1983, Knežević 1994, Zlatković \& al. 2005). According to Popescu (2005a) recent distribution of Crypsidetum aculeatae in Romania is limited; the community still occurs in regions of Muntenia, Moldova, Dobrogea and in the Danube Delta. The author supposes that the community presently covers an area of approximately 5-10 hectares only and that conservation of the association is inadequate. Similarly, Micevski's Crypsidetum aculeatae balcanicum has recently been threatened by limited distribution and is under direct destruction (Matevski \& al. 2003). Apart from Slovakia, the community is also missing in the Czech Republic (Danihelka \& Hanušová 1995, Dítě 2006 ined., Šumberová 2007) and moreover the species survive there thanks only to human support (Holub \& Grulich 1999a).

\subsection{Communities with dominance of Heleochloa schoenoides in Slovakia}

Occurrence of vegetation with dominance of Heleochloa schoenoides was recorded at several localities during recent times. In 2004 we found typical vegetation mainly at the bottom of a small periodical pool near the Tvrdošovce railway station, (Tab. 1, relevés 1,2 , Fig. 6). It was distinguished by great dominance of the species (nearly $100 \%$ ) and low richness and abundance of other species ( 5 species in relevés with abundance to $5 \%$ ). Similar vegetation was found at a periodically flooded habitat of a field depression in the surroundings of the village of Močenok in 2006 (Tab. no. 1, relevés no. 12, 16-20). However, also many synanthropic species grew there. Other habitats of Heleochloa schoenoides were found on field margins and at open places strongly affected by man (field depressions, field roads, wet fallows, Fig. 7). The presence of ruderal species was caused by lower soil salinity and direct contact with intensively managed fields. Therefore

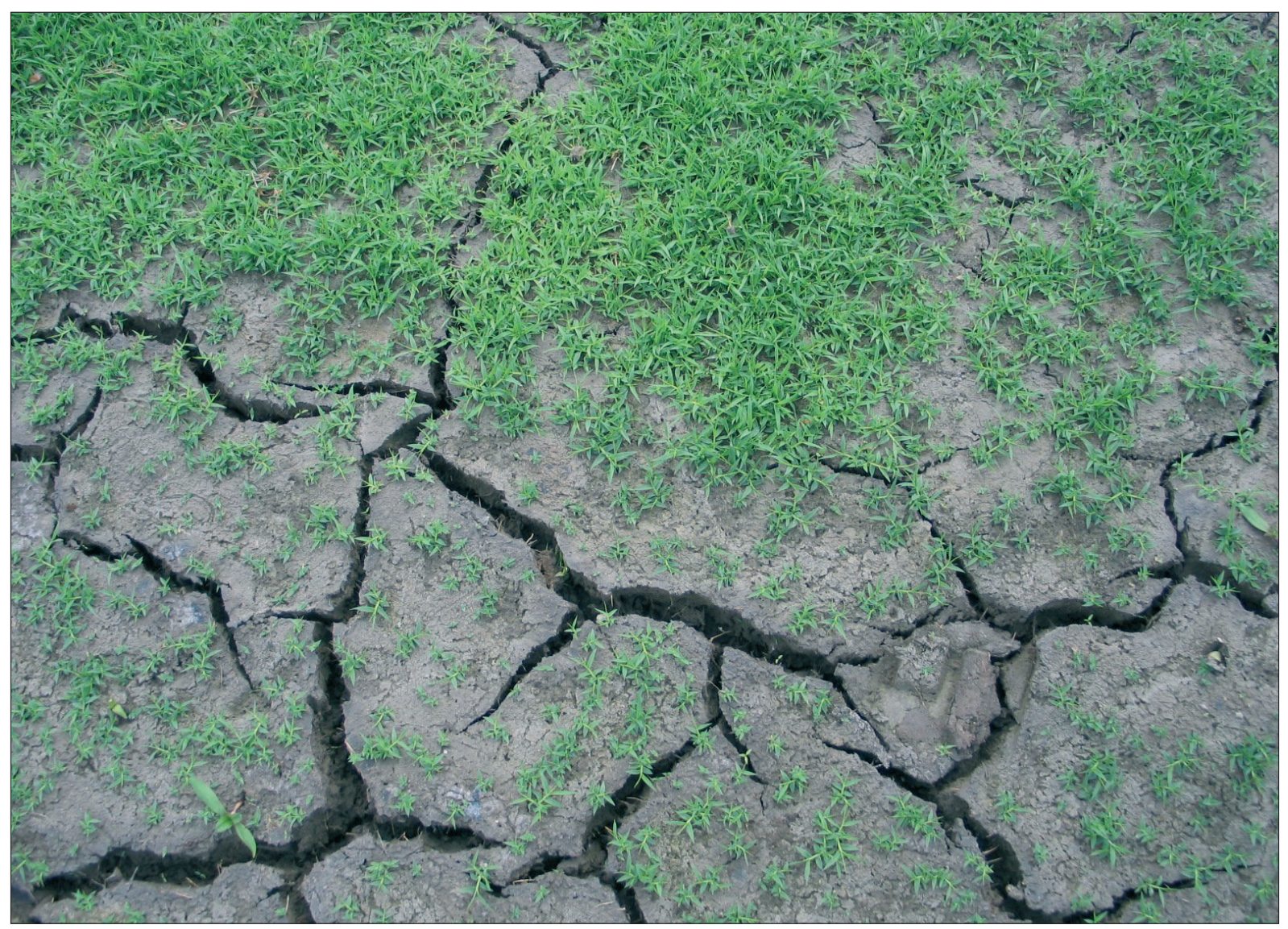

Figure 6: Heleochloetum schoenoidis on drying lake bank in Tvrdošovce. Photo: P. Eliáš jun., 30. 8. 2004.

Slika 6: Heleochloetum schoenoidis na izsušenem jezerskem bregu pri vasi Tvrdošovce. Foto: P. Eliáš jun., 30. 8. 2004. 
this vegetation was modified and the presence of many ruderal plant species was recorded (e. g. Amaranthus retroflexus, Atriplex sagittata, A. tatarica, Echinochloa crus-galli, Lepidium ruderale, Polygonum rurivagum etc.). In some extreme cases the cover of ruderal species was close to $50 \%$ per plot. Despite this fact, all samples in Slovakia can be assigned to the association Heleochloetum schoenoidis (Soó 1933) opa 1939 [syn. Crypsidetum schoenoidis (Soó 1938) T,opa 1939] even though they are more or less ruderalized. In some cases, when the soil salinity was low, we found a transition to communities of the class Isoëto-Nanojuncetea (e.g. on a dry bed of a small pool in Komárno - Ďulov dvor farmstead). The same pattern was recorded by Šumberová (2007) in degraded saline pools of Southern Moravia. We suppose that this change is probably irreversible and will result in full extinction of the community.

The community is distributed in the Ponticpannonian region (Vicherek 1973). Reliable data about its occurrence were given from the Czech Republic (Vicherek 1. c., Šumberová 2007), Slovakia (Krist 1940, Vicherek 1964, 1973, Sádovský \& al. 2004b), Hungary (e. g. Soó 1940, 1947, Bodrogközy 1962, Borhidi 1996, Molnár \& Borhidi 2003), Romania (Țopa 1939, Pop 2002, Popescu 2005b), and Mongolia (Hilbig 2000). Following Hilbig's data Šumberová (2007) suggested the occurrence of the community in Ukraine and in steppe areas of southern Russia. Nevertheless, the community was not mentioned in published surveys of saline vegetation of Ukraine and Russia (Solomakha 1996, Freitag \& al. 2001, Voityuk 2005). This stage could also be caused by different syntaxonomical treatment of the Heleochloa schoenoides communities.

Vicherek (1973) mentioned that Heleochloetum schoenoidis included two subassociations on the territory of the former Czechoslovakia: subass. typicum and subass. spergularietosum marginatae. Similarly as in the case of Crypsidetum aculeatae association the presence of 3-5 plant species was typical for subass. typicum. The second subassociation was characterised by slightly higher species richness (7-9 plant taxa per relevé). In our relevés it was approximately two times greater due to penetration (invasion?) of ruderal species (8-16 plant species per relevé, Tab. 1). Therefore it is now impossible to distinguish the above mentioned subassociations. Heleochloetum schoenoidis sites were mainly on the area of agricultural crops and they were usually destroyed in years with dry weather. The same stage was pointed out by Šumberová (2007); the author reported ca. 10 species per plot.

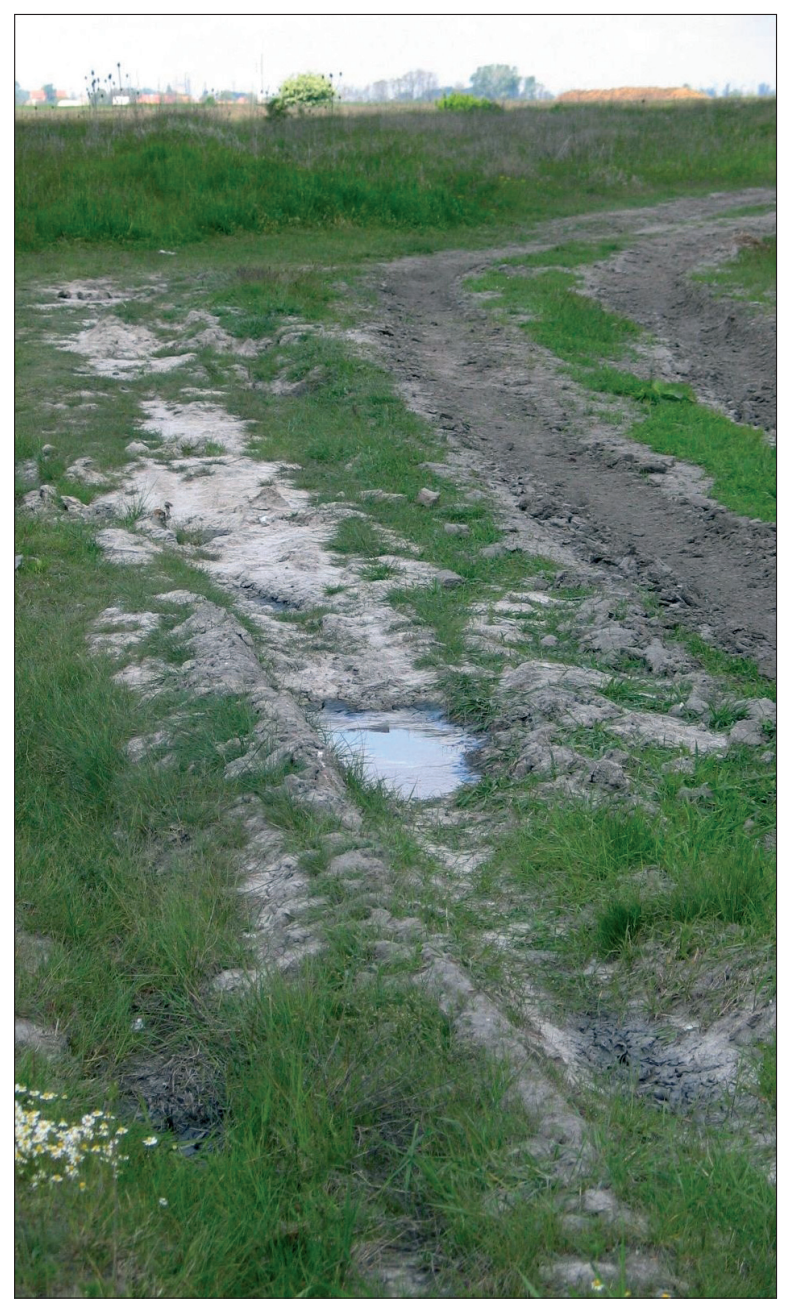

Figure 7: Rural roadside - a secondary habitat of Heleochloa schoenoides. Photo: P. Eliáš jun., 16. 7. 2005

Slika 7: Kolovoz - nadomestni habitat vrste Heleochloa schoenoides. Foto: P. Eliáš jun., 16. 7. 2005

The comparative findings were made near the villages of Solt (Table 1, relevés no. 13, 14) and Balmazújváros in Hungary (Table 1, relevé no. 11). Only ruderalized Heleochloetum schoenoidis vegetation was found and the community was established just on secondary habitats (field depressions, field margins). Despite our findings, the community is the most common in Hungary; the occurrence was mentioned mainly from the large region of the Great Hungarian Plain (Soó 1939, 1964). In this region approximately 1200 ha of saline lakes and 13,000 ha of salt meadows and marshes were mentioned (Molnár \& Varga 2000). However, Varga \& Várgáné (1999b) have recently included the association into the Red book of Hungarian vegetation. Distribution in Romania is very scattered, Popescu 
(2005b) mentioned the community mainly from districts of Transylvania, Banat, Muntenia, and Moldova. The author estimated that the total area covered by Heleochloetum schoenoidis is no larger than 35-40 hectares, and the community needs active protection. The association is infrequent in Serbia as well (Knežević 1990, Kojić \& al. 1998). It is centralised in the Vojvodina region and some localities are situated in the central and southern part of the country. The community is also very rare in the Czech Republic, recent occurrence was confirmed in south-eastern Moravia (Danihelka \& Hanušová 1995, Šubmerová 2007). These data suggest that the community is presently uncommon in the whole of Central and Eastern Europe.

\section{CONCLUSIONS}

A stronger decrease of saline areas was recorded in the last 30-40 years in the Czech Republic and Slovakia. Most of the habitats were fully destroyed by agriculture and construction activities (Sádovský et al. 2004b). The small fragments were conserved to the present time, but the habitats are situated among crop fields where the water regime is being changed. Habitat degradation caused changes of vegetation cover. Soil salinity has decreased and the attack of weedy species has been recorded. Because Crypsis aculeata is unable to adapt to these changes the number of localities markedly decreased and the species is threatened with extinction. Typical communities with dominance of the species were not found at two still existing micro-sites. It survived scattered in ruderalized vegetation. On the other hand, Heleochloa schoenoides is partly adapted to the ecologically changed conditions and thus historical and present distribution of the species is practically identical. But the Heleochloa schoenoides communities were modified dramatically - they occurred usually at secondary habitats and the ruderal species were very abundant. Finally, our data pointed out that Crypsis aculeata and Heleochloa schoenoides communities are now endangered in the whole Pannonian region.

\section{ACKNOWLEDGEMENTS}

We are grateful to Milan Valachovič (Bratislava, Slovakia) for valuable comments and contributions, Viktor Kerényi-Nagy (Budapest, Hungary) for his help with the herbarium data excerption.
We are indebted to Rozália and Zoltán Orosi (Harta, Hungary) and Alexander Fehér (Nitra, Slovakia) for help with field research in Hungary. This paper was particularly supported by the grants of the Grant Agency for Science "VEGA", Bratislava, Slovakia (grants No. 1/3446/06 and No. 1/0672/08) and of the Ministry of Education of the Czech Republic (grant no. 0021622416).

\section{REFERENCES}

Barkmann, J. J., Doing, H. \& Segal, S. (1964): Kritische Bemerkungen und Vorschläge zur quantitativen Vegetationsanalyse. Acta Botanica Neerlandica, Amsterdam, 13: 394-419.

Bilik, G. J. (1937): Roslinnis zasolenich ugid' livoberežžja serednoi Naddniprjanščini. Geobotaničeskij zbirnik, Kijiv, 1: 85-118.

Bilik, G. J. (1963): Roslinnis zasolenich gruntiv Ukraini, ii rozvitok, bikoristanija ta polišennja. Kijiv, Vydavnictvo AN URSR, 300 pp.

Bodrogközy, G. (1962): Die standortsökologischen Verhältnisse der halophilen Pflanzengesellschaften des Pannonicum I. Untersuchungen an den Solontschak-Szikböden des südlichen Kiskunság. Acta Botanica Academiae Scientiarum Hungaricae, Budapest, 8: 1-37.

Bojko, H. (1931): Ein Beitrag zur Ökologie von Cynodon dactylon Pers. und Astragalus exscapus L. Sitzungsberichte der Akademie der Wissenschaften in Wien, Mathematisch-naturwissenschaftliche Klasse, Wien, 140: 675-692.

Bojko, H. (1932): Über die Pflanzengesellschaften im burgenländischen Gebiete östlich vom Neusiedler-See. Burgenlandische Heimatblatt, Eisenstadt, 1: 43-54.

Borhidi, A. (1996): An annotated checklist of the Hungarian plant communities. I. The non-forest vegetation. In: Borhidi, A. (ed.): Critical revision of the Hungarian plant communities, Janus Pannonius Univ. Pécs, pp. 43-94.

Boros, E. (2003): Alkaline lakes, National Ecological Network 4. Authority for Nature Conservation, Ministry of Environment and Water, Budapest, Hungary. 28 pp.

Buol, S. W., Hole, F. D., McCracken, R. J. \& Southard R. J. (1997): Soil genesis and classification. Iowa State University Press, Ames, 406 pp.

Conert, H. (1983): Crypsis L. Illustrierte Flora von Mitteleuropa, Band I, Teil 3, Lieferung 2. Paul Parey, Berlin \& Hamburg, pp. 99-105. 
Danihelka, J. \& Hanušová, M. (1995): Poznámky k současnému stavu slanomilné flóry a vegetace v okolí Nesytu u Sedlce. Zprávy České botanické společnosti, Suppl. 1995/1: 135-146.

Dítě, D., Eliáš ml., P. \& Sádovský, M. (2004): Recentný výskyt halofytov v Liptovskej a Spišských kotlinách (severné Slovensko). Bulletin Slovenskej botanickej spoločnosti, Bratislava, Supl. 10: 117-121.

Feráková, V., Maglocký, Š. \& Marhold, K. (2001): Červený zoznam paprad'orastov a semenných rastlín. In: Baláž, D., Marhold, K. \& Urban, P. (eds.): Červený zoznam rastlín a živočíchov Slovenska. Ochrana prírody, Banská Bystrica, (Suppl.) 20: 44-76.

Freitag, H., Golub, V. B. \& Yuritsyna, N. A. (2001): Halophytic plant communities in the northern Caspian lowlands: 1. annual halophytic communities. Phytocoenologia 31 (1): 63-108.

Futák, J. \& Domin, K. (1960): Bibliografia k flóre ČSR. Vyd. SAV, Bratislava, 884 pp.

Futák, J. (1980): Fytogeografické členenie SSR (1 : 1000 000). In: Mazúr E. (ed.): Atlas Slovenskej socialistickej republiky. Bratislava, p. 81.

Grulich, V. (1987): Slanomilné rostliny na jižnî Moravě. Okresní výbor Českého svazu ochránců přírody, Břeclav, p. 76.

Hennekens, S. M. \& Schaminée, J. H. J. 2001: TURBOVEG, a comprehensive data base management system for vegetation data. Journal of Vegetation Science 12 (4): 589-591.

Hejný, S. (1960): Ökologische Charakteristik der Wasser und Sumpfpflanzen in den Slowakischen Tiefebennen. Vydavatelstvo SAV, Bratislava, 487 pp.

Hilbig, W. (2000): Kommentierte Übersicht über die Pflanzengesellschaften und ihre höheren Syntaxa in der Mongolei. Feddes Repertorium 111: 75-120.

Holub, J. \& Grulich, V. (1999a): Crypsis aculeata (L.) Aiton. In: Čeřovský, J. \& al. (eds.): Červená kniha ohrozených a vzácnych druhov rastlín a živočíchov SR a ČR Vol 5. Vyššie rastliny. Príroda, Bratislava, p. 119.

Holub, J. \& Grulich, V. (1999b): Heleochloa schoenoides (L.) Host ex Roemer. Čeřovský J. \& al. (eds.): Červená kniha ohrozených a vzácnych druhov rastlín a živočíchov SR a ČR Vol 5. Vyššie rastliny. Príroda, Bratislava, p. 178.

Holub, J. \& Procházka, F. (2000): Red List of vascular plants of the Czech Republic. Preslia 72: 187-230.

Holub, J. (1999): Schoenoplectus supinus (L.) Palla.
In: Čeřovský, J. \& al. (eds.): Červená kniha ohrozených a vzácnych druhov rastlín a živočíchov SR a ČR Vol 5. Vyššie rastliny. Príroda, Bratislava, p. 332.

Knežević, A. S. (1994): Monografija flore vaskularnih biljaka na slatinama u regionu Banata, (Jugoslavija). Matica srpska, Novi Sad, p. 122.

Kojić, M., Popović, R. \& Karadžić, B. (1998): Sintaksonomski pregled vegetacije Srbije. Institut za biološka istraživanja „Siniša Stanković“, Beograd, pp. 5-218.

Körner, I. (2006). Die Pflanzenweld rund um den Neusiedler See. In: Oberleitner, I., Wolfram, G. \& Achatz-Blab, A. (eds.): Salzlebensräume in Österreich. Umweltbundesamt, Wien, pp. 109117.

Krippelová, T. (1965): Sol’né stepi na Žitnom ostrove. Československá ochrana prírody, Bratislava, 2: 121-133.

Krist, V. (1940): Halofytní vegetace jihozápadního Slovenska a severní části Malé Uherské nížiny. Práce Moravské přírodovědecké společnosti, Brno, 12/10: 1-100.

Kupčok, S. T. (1956): Príspevok k poznaniu flóry okolia Banskej Štiavnice a Pukanca. Biologické práce 2(9): 1-64.

Marhold, K. \& Hindák, F. (eds.) (1998): Zoznam nižších a vyšších rastlín Slovenska. Veda, Bratislava, 688 p.

Matevski, V., (2003): Dryland/grassland ecosystems. In: Smith, D. R. \& Smith, K. A. (eds.): Country Study for Biodiversity of the Republic of Macedonia (First National Report). Ministry of Environment and Physical Planning, Skopje, p. 44.

Micevski, K. (1965): Halofitska vegetacija Ovčeg Polja. Acta Musei Macedonici Scientiarum Naturalium, Skopje, 10: 67-90.

Molnár, Zs. \& Borhidi, A. (2003): Hungarian alkali vegetation: Origins, landscape history, syntaxonomy, conservation. Phytocoenologia 33: 377408.

Molnár, Zs. \& Vajda, Z. (eds.) (2000): A Duna-Tisza köze aktuális élõhely-térképezése. Kézirat, Vácrátót-Kecskemét, 27 pp.

Mucina, L. \& Maglocký, ̌́. (eds.) (1985): A list of vegetation units of Slovakia. Documents phytosociologiques, Camerino, 9: 175-220.

Mucina, L. (1993): Puccinellio-Salicornietea. In: Mucina, L., Grabherr, G. \& Ellmauer, T. (eds.): Die Pflanzengesellschaften Österreichs. Teil 1, Anthropogene Vegetation. Fischer, Stuttgart, New York, pp. 522-549. 
Niklfeld, H. \& Schratt-Ehrendorfer, L. (1999): Rote Liste gefährdeter Farn- und Blütenpflanzen (Pteridophyta und Spermatophyta) Österreichs. 2. Fassung. In: Niklfeld, H. (ed.): Rote Listen gefährdeter Pflanzen Österreichs, ed. 2, Grüne Reihe des Bundesministerium für Umwelt, Jugend und Familie, Wien, pp. 33-151.

Niklfeld, H. (1971): Bericht über die Kartierung der Flora Mitteleuropas. Taxon 20: 545-571.

Novák, F. A. (1954): Přehled československé květeny s hlediska ochrany přírody a krajiny. In: Veselý, J. (ed.): Ochrana československé přírody a krajiny 2: 193-409.

O’Leary, J. \& Glenn, E. (1994): Global distribution and potential for halophytes. In: Squires, V. R. \& Ayoub, A. (eds.): Halophytes as a Resource for Livestock and for Rehabilitation of Degraded Land, Tasks in Vegetation Science Series, Kluwer Academic Press, The Netherlands.

Osvačilová, V. \& Svobodová, Z. (1961): Floristickofytocenologický prieskum Nitrianskeho kraja (tématická mapa). Msc., $10 \mathrm{p}$.

Pop, I. (2002): Vegetatia solurior saraturoase den Romania. Conributtii Botanice 35 (2): 287332.

Popescu, A. (2005a): Comunitãţi vest-pontice cu Crypsis aculeata. In: Doniță, N., Popescu, A., Pauc -Comănescu, M., Mihăilescu, S., Biriş, I. A.: Habitatele din România. Edit. Tehnică Silvică, Bucureşti, pp. 40-41.

Popescu, A. (2005b): Comunitãţi vest-pontice cu Heleochloa schoenoides. In: Doniță, N., Popescu, A., Pauc -Comănescu, M., Mihăilescu, S. \& Biriş, I. A., Habitatele din România. Edit. Tehnică Silvică, Bucureşti, p. 43.

Sádovský, M., Eliáš, P., ml. \& Dítě, D. (2004a): Poznámky k rozšíreniu a cenológii vybraných druhov halofytných rastlín na juhozápadnom Slovensku. Bulletin Slovenskej botanickej spoločnosti, Bratislava, Supl. 10: 122-126.

Sádovský, M., Eliáš, P., ml. \& Dítě, D. (2004b): Historické a súčasné rozšírenie slaniskových spoločenstiev na juhozápadnom Slovensku. Bulletin slovenskej botanickej spoločnosti, Bratislava, Supl. 10: 127-129.

Schratt-Ehrendorfer, L. (1999): Zur Flora und Vegetation des österreichschen March- und Thaya-Tales. In: Kelemen, J. \& Oberleitner, I. (eds.): Fließende Grenzen. Lebensraum March-ThayaAuen, Umweltbundesamt, Wien, pp. 181-202.

Slavnić, Ž. (1948): Slatinska vegetacija Vojvodine. Arhiv za poljoprivredne nauke i tehniku, Novi Sad, 3: 1-80.
Šmarda, J. (1961): Vegetační poměry Spišské kotliny. SAV, Bratislava, 268 pp.

Solomakha, V. A. (1996): The syntaxonomy of vegetation of the Ukraine. Ukrainian Phytosociological Collection, Ser. A, 4/5: 1-121.

Soó, R. (1939): Homokpusztai és sziki növényszövetkezetek a Nyirségen. Botanikai Közlemenyek, Budapest, 35: 90-108.

Soó, R. (1940): Vergangenheit und Gegenwart der pannonischen Flora und Vegetation. Nova Acta Leopoldiana, N. F., Halle (Saale), 9: 1-49.

Soó, R. (1947): Conspectus des groupements végétaux dans les Bassins Carpathiques. I. Les associations halophiles. Debrecen, 60 pp.

Soó, R. (1964): A magyar flóra és vegetáció rendszertani-növényföldrajzi kézikönyve I. Akadémiai Kiadó, Budapest, pp 589.

Šumberová, K. (2007): Vegetace jednoletých halofilních travin (Crypsietea aculeatae). In: Chytrý, M (ed.): Vegetace ĆR 1, Academia, Praha, pp. 132-142.

Šumberová, K., Grulich, V. \& Danihelka, J. (2000): Flóra cévnatých rostlin. In: Vicherek, J. et al.: Flóra a vegetace na soutoku Moravy a Dyje, Masarykova Univerzita, Brno, pp. 107-180.

Szabolcz, I. (1991): Desertification and salinization. International conference on agricultural management in salt-affected areas. Agadir, Morroco, p. 23-24.

Tichý, L. (2002): JUICE - software for vegetation classification. Journal of Vegetation Science, 13: 51-453.

Timár, L. (1954): Egyéves növénytársulások a Szeged környékiszikesek iszapján. I. Annales Biologici Universitatis Hungariae, II. Pars, Debrecen, Budapest, 2: 311-321.

Țopa, E. (1939): Vegeta ia halofitelor din Nordul României. Bulletin Faculti Sțiintele Cernăuți 13: 1-80.

Valachovič, M. (1995): Zonácia halofytnej vegetácie na slanisku pri Tvrdošovciach (Západné Slovensko). Bulletin Slovenskej botanickej spoločnosti, Bratislava, 17: 27-39.

Varga, Z. \& Várgáné, S. J. (1999a): Crypsidetum aculeate Wenzl 1934. In: Borhidi, A. \& Sánta, A. (eds.): Vörös könyv magyarorsyág növénytársulásairól 1. Termászet BÚVÁR Alapítvány Kiadó, Budapest, p. 261-262.

Varga, Z. \& Várgáné, S. J. 1999b. Heleochloetum schoenoidis (Soó 1933) Topa 1939. In: Borhidi, A. \& Sánta, A. (eds.): Vörös könyv magyarorsyág növénytársulásairól 1. Termászet BUVÁR Alapítvány Kiadó, Budapest, p. 262. 
Vicherek, J. (1962): Rostlinná společenstva jihomoravské halofytní vegetace. Publications de la faculté des sciences de l’université á J. E. Purkyně, Brno, 430: 65-96.

Vicherek, J. (1964): K rozšîření halofytní květeny na jihovýchodním Slovensku (Košická kotlina, Potiská nížina). Biológia, Bratislava, 19: 555557.

Vicherek, J. (1973): Die Pflanzengsellschaften der Halophyten und Subhalophytenvegetation der Tschechoslowakei. Vegetace ČSSR, ser. A, Praha, 5: 79-90.

Voityuk, B. Yu. (2005): Halophytic vegetation of the North-West Black Sea coast (in Ukrainian). Kijiv, pp. 256.

Vozárová, M. \& Sutorý, K. (2001): Index herbariorum Reipublicae bohemicae et Reipublicae slovacae. Zprávy České botanické společnosti, Praha, 36, Př́loha 2001/1; Bulletin Slovenskej botanickej spoločnosti, Bratislava, Suppl. 7, 95 pp.

Vučković, R. (1983): Asocijacijski kompleks halofitske vegetacije na lokalitetu Deračka bara u srednjem Banatu. In: Mihaljev, I. \& Vučić, N. (eds.): Čovek i biljka, Matica srpska, Novi Sad, p. 469-478.

Wendelberger, G. (1959): Die Vegetation des Neusiedler See-Gebietes. Sitzungsberichte der ÖesterreichischeAkademiederWissenschaften, Mathematisch-naturwissenschaftliche Klasse, Wien, 168: 305-314.

Zlacká, S. (2006): Heleochloa schoenoides (Report). In: Dítě, D. (ed.): Zaujímavejšie floristické nálezy. Bulletin Slovenskej botanickej spoločnosti, Bratislava, 28: 283.

Zlatković, B., Ranđelović, V. \& Amidžić, L. (2005): Novi podaci o flori slatina Centralne i Južne Srbije. In: Ranđelović, N. (ed.): 8th Symposium on the Flora of Southeastern Serbia and Neighbouring Regions, Abstracts. Prirodno-matematički fakultet, Nišs, p. 36-37.

\section{APPENDIX}

List of localities of Crypsis aculeata:

a) Herbarium specimens and confirmed literature references

6. Nový Život, part Eliášovce (Mergl 1902 SAV). - Vel'ké Kosihy, salt pasture near (Májovský 1963 SLO; Májovský \& al., Acta Fac. Rer. Natur. Univ. Comen., Bot. XXIII: 7, 1974). - Zlatná na Ostrove (Weber 1936 BRA; 1949 BRNM; Vicherek 1973). - Komárno, near the railway station (Futák 1949 ined., Šmarda 1951 BRNM; Smejkal 1951 BRNU; Šourek 1951 PR). - Hájske, Mešterik farmstead (Weber 1918 BRNM, 1935 BRA). -

Močenok, Siky farmstead (Weber 1935 BRA; Krist 1937 BRNU; Krist 1940; Valenta 1938 BRA). - Dolný Jatov (Weber 1935 BRA; Futák 1949 ined.). - Vel'ká Dolina, Kokaš farmstead, saline drainage chanel (Osvačilová 1953 NI). - Tvrdošovce (Weber 1935 BRA; Vozárová 1994 BRA; Eliáš jun. Dítě, Kolník \& Sádovský 2002 NI; Grulich 2002 BRNU - near the railway station). - Tvrdošovce, small fishpond on northern margin of the village (Grulich 1985 MMI; Pluhař 1986 BRNU; Grulich \& Kochjarová 1988 SLO). - Palárikovo, near railway station (Weber 1936 BRA). - Palárikovo, Vel'ké Čiky farmstead (Weber 1933 BRNM; Smejkal 1965 BRNU). - Palárikovo, Malé Čiky [= Čiastka] farmstead (Weber 1935 BRA; Valenta 1937 BRA; Krist 1938 BRNU, Krist; 1940). - Palárikovo, Bačala farmstead (Weber 1935 BRA). - Búč (Dvořák 1965 BRA; Unar 1965 BRNU, Vicherek 1973).

b) Literature references without confirmation of herbarium specimens:

4. The Záhorská nížina lowland (Novák 1954) [not mapped]. 6. Tôn, wetland site in the village surrounding (Futák 1949 ined.). - Opatovský Sokolec, southern margin of the village (Vicherek 1973). - Okoč, southern margin of the village (Vicherek 1973). - Kl'účovec, bank of small pond in the village (1975) (Svobodová 1988: 11). - Malé Kosihy, in the village (Vicherek 1973). - Žihárec, near the railway station (Vicherek 1973). - Palárikovo, Horný Jur farmstead (Futák 1949 ined.). - Chotín, bank of small pond in the village (1974) (Svobodová 1988: 11). - Pribeta, saline site near railway station (Futák 1949 ined.). - Mužla (Feichtinger 1899: 392; Domin 1933: 247). - Nána (Feichtinger 1899: 392; Domin 1933: 247). - Kamenín (Feichtinger 1899: 392; Domin 1933: 247).

List of localities of Heleochloa schoenoides:

2. Zalaba (Hejný 1951 SLO). 4. Záhorská nížina lowland, saline soils (Novák 1954) [not mapped].

6. Bratislava, wetlands near Istrochem factory (Feráková 1972 SLO). - Bratislava-Vajnory, Čierna Voda farmstead (Ondrášek 1986 MMI). - Svätý Jur, Pálffyovský dvor farmstead (Holuby 1913 PRC). - Svätý Jur, site Š́r (Zigmundík 1913 BRA; Holub \& Grulich 1999b) [data probably refer to the previous]. - Hájske (Krist 1936 BRNU, 1937 BRNU; Weber 1931 BRNM, 1937 BRA; Krist 1940; Vicherek - SW margin of the village; Sádovský \& al. 2004a). 
- Hájske, Mešterik farmstead (Weber 1935 BRA, 1936 BRNM; Krist 1937 BRNU; Klokner 1955 SLO; Weber 1970 PR, 1977 PR; Eliáš jun. \& Dítě 2005 NI). - Močenok, Síky farmstead (Weber 1935 BRA, 1936 BRNM; Krist 1937 BRNU; Krist 1940; Klokner 1955 SLO; Unar 1965 BRNU ut "salt meadow Močenok"; Weber 1970 PR, 1977 PR; Eliáš jun. \& Dítě 2005 NI). - Cabaj-Čapor, Szík farmstead [locality probably refers to the previous] (Vlach 1935 PRC). - Šal'a, Andelek farmstead (Weber 1936 BRNM). - Trnovec nad Váhom, near the railway station (Weber 1935 BRA, 1936 BRNM). - Horný Jatov (Krist 1936 BRNU; Weber 1936 BRNM; Sádovský 2002 NI). - Dolný Jatov, Čierny vršok farmstead (Osvačilová 1953 PRC, Dostál 1955 PRC). Dolný Jatov (Weber 1935 BRA, 1936 BRNM; Holub \& Grulich 1999b; Grulich 1988 MMI - wet place 1 km SSW from the village). - Polný Kesov (Dostál 1955 PRC). - Komjatice, Ružový dvor farmstead (Vlach 1934 PRC; Krist 1940; Sádovský \& al. 2004a). - Tvrdošovce (Krist 1924 BRNU, 1936 BRNU; Krist 1940; Weber 1935 BRA, 1936 BRA, BRNM; Pospíšil 1952 BRNM; Pokluda 1961 BRNM; Dostál 1966 PR; Vicherek 1973 - small fishpond on N part of the village; Weber 1977 PR; Grulich 1985 MMI - small fishpond on N part of the village; Grulich 1985 MMI - wet pastures on NW part of the village; Grulich $1986 \mathrm{MMI}-1.5 \mathrm{~km}$ NW from the railway station; Pluhař 1986 BRNU; Grulich \& Kochjarová 1988 SLO; Vozárová 1994 BRA; Svobodová 1994 NI; Eliáš jun., Dítě, Kolník \& Sádovský 2002 NI). - Palárikovo (Krist 1924 BRNU; Krist 1940; Scheffer 1923 BRNU - in agris; Weber 1935 BRA, 1936 BRNM; Skřivánek 1948 BRNM; Futák 1949 SLO; Dvořák 1952 BRNM; Pospíšil 1952 BRNM; Šourek 1954 PR - NW from the railway station; Pokluda 1961 BRNM; Vicherek 1973 - NE margin of the village; Grulich 1985 MMI - NW from the railway station; Holub \& Grulich 1999b). - Palárikovo, Berchtold farmstead (Weber 1936 BRNM). - Palárikovo, Bačala farmstead (Weber 1935 BRA, 1936 BRNM). - Palárikovo, Vel'ké Čiky farmstead (Weber 1936 BRNM; Klokner 1955 SLO; Smejkal 1965 BRNU; Unar 1965 BRNU ut Heleochloa alopecuroides). - Palárikovo, Malé Čiky farmstead [= Čiastka] (Weber 1933 BRNM, 1935 BRA, 1936 BRNM; Krist 1937 BRNU; Krist 1940; Weber 1977 PR; Grulich 1988 MMI; Eliáš jun. \& Sádovský 2003 NI). - Šurany, Akomáň farmstead (Weber 1936 BRNM; Weber 1977 PR; Grulich 1987 MMI; Holub \& Grulich 1999b). - Malá Maňa, small fishpond in the village (Vicherek 1973). - Žihárec, small fishpond near the railway station (Vicherek 1973). - Tôň
(Futák 1949 SAV; Vicherek 1973). - Okoč (Krist 1940; Vicherek 1973). - Vel'ké Kosihy (Májovský 1963 SLO; Holub \& Grulich 1999b). - Okánikovo, Mostové Nature Reserve [= Dérhidia] (Čvančara \& Šourková 1972 BRNM, BRNU, PR; Grulich 1986 MMI; Eliáš jun. \& Dítě 2004 NI). - Okoličná na Ostrove, near the railway station (Májovský 1963 SLO; 1966 SLO, 1969 SLO). - Okoličná na Ostrove, Ekelský dvor farmstead (Krippelová \& Zahradníková 1962 SAV). - Zlatná na Ostrove (Valenta 1936 BRA; Weber 1936 BRA, BRNM, 1937 BRNM; Šourek 1954 PR; Hajdúk \& Krippelová 1962 SAV; Holub \& Grulich 1999b; Grulich 1987 MMI - 0.5 $\mathrm{km}$ E from the railway station). - Kameničná (Feráková 1971 SLO; Řehořek \& Svobodová 1971 NI ut Crypsis aculeata). - Komárno, osada Pavel (Klokner 1966 PMK). - Komárno, osada Nová Stráž (Krist 1940; Magic 2002 BRA). - Komárno, near railway station (Nábělek 1936 BRA; Hrabětová 1947 BRNU ut Crypsis aculeata; Hrabětová 1951 BRNU - field margin; Dvořák 1952 BRA; Smejkal 1951 BRNU; Šmarda 1951 BRNM; Hejný 1953 PR; Šourek 1954 PR). - Komárno, Duulov dvor farmstead (Klokner 1967 PMK; Eliáš jun. 2003 NI). - Chotín (Futák 1949 SLO; Šourek 1954 PR - W from elevation point $109 \mathrm{~m}$ ). - Iža, Bokroš hamlet (Svobodová 1991 NI; Eliáš jun., Dítě \& Sádovský 2006 NI) . - Pribeta (Klika 1937 PR). - Búč (Feichtinger 1899: 392; Májovský 1963 SLO; Vicherek 1963 BRNU, Biológia, 19: 463, 1964; Dvořák 1965 BRA; Čvančara 1970 BRNM, 1971 PR; Nevrlý 1971 BRNM; Dorotovičová 1994 PMK; Eliáš jun., Dítě \& Sádovský 2005 NI). - Gbelce (Krist 1936 BRNU; Vicherek 1973). Mužla (Feichtinger 1899: 392; Domin 1933v: 247; Šmarda 1949 BRNM; Májovský 1963 SLO; Eliáš jun. \&. Sádovský 2006 NI). - Štúrovo, Boží kopec hill, waterbank of the Danube (Hejný 1953 PR). - Nána (Feichtinger 1899: 392; Domin 1933v: 247). - Kamenný Most, Čistiny Nature Reserve [= Irtoványi rétek] (Šourek 1954 PR). - Kamenín (Feichtinger 1899: 392; Domin 1933v: 247; Klika 1931 NI, 1936 NI; Nábělek 1936 SAV; Weber 1936 BRNM; Futák 1948 SLO; Osvačilová 1956 NI ut Crypsis aculeata; Černoch, Biológia, 15/11: 818, 1960; Májovský 1965 SLO; Řehořek 1981 NI; Murín, Feráková \& Činčura 1982 SLO; Grulich 1985 MMI; Svobodová 1982 NI; Eliáš jun. 2005 NI) . 8. Kačanov, S obce (Vicherek, Biológia 19: 556, 1964). - Malčice, 2 km SW from the village (Vicherek, Biológia 19: 556, 1964). - Beša (Zlacká 2005 NI). - Somotor, under northern slope of Tarbucka hill (Vicherek, Biológia 19: 556, 1964). - Viničky, river branch of the Bodrog River (Májovský 1964 SLO). - Vel'ký Kamenec, S 
from the village (Vicherek 1962 BRNU; Vicherek, Biológia 19: 556, 1964). - Vel'ký Kamenec, hamlet Bukov [= Ružový dvor farmstead?], river branch Vel'ká Krčava (Hejný 1953 PR). - Strážne, waterbank of Krčava canal $3 \mathrm{~km}$ W from the village (Vicherek, Biológia 19: 556, 1964). - Malý Horeš, SW from the village (Vicherek, Biológia 19: 556, 1964).
- Leles, $3 \mathrm{~km} \mathrm{~N}$ from the village (Vicherek Biológia 19: 556, 1964). - Leles, Kapoňa hamlet, sandy field south from the village (Májovský \& Záborský 1961 SLO). - Ruská, in the village (Vicherek, Biológia 19: 556, 1964; Vicherek 1973). - Morčany, W from the village (Vicherek, Biológia 19: 556, 1964) [not mapped; unidentified locality].

Table 1: Analytical table of recent Crypsis aculeata and Heleochloa schoenoides plant communities in Slovakia and Hungary.

Tabela 1: Analitična tabela recentnih rastlinskih združb s Crypsis aculeata in Heleochloa schoenoides na Slovaškem in Madžarskem.

\begin{tabular}{|c|c|c|c|c|c|c|c|c|c|c|c|c|c|c|c|c|c|c|c|c|c|c|}
\hline Relevé number: & 1 & 2 & 3 & 4 & 5 & 6 & 7 & 8 & 9 & 10 & 11 & 12 & 13 & 14 & 15 & 16 & 17 & 18 & 19 & 20 & 21 & 22 \\
\hline Relevé surface $\left(\mathbf{m}^{2}\right)$ & 16 & 16 & 10 & 8 & 4 & 2 & 10 & 9 & 8 & 16 & 12 & 16 & 8 & 16 & 16 & 16 & 16 & 16 & 9 & 8 & 16 & 10 \\
\hline Coverage $E_{1} \%$ & 80 & 95 & 45 & 35 & 75 & 35 & 70 & 60 & 60 & 70 & 25 & 95 & 55 & 60 & 45 & 85 & 80 & 45 & 60 & 70 & 45 & 45 \\
\hline Coverage $\mathrm{E}_{0} \%$ & 0 & 0 & 0 & 0 & 0 & 0 & 0 & 0 & 0 & 0 & 0 & 0 & 0 & 0 & 0 & 0 & 2 & 0 & 0 & 0 & 0 & 0 \\
\hline Number of species per relevé & 5 & 5 & 7 & 7 & 8 & 6 & 16 & 12 & 9 & 14 & 8 & 15 & 13 & 11 & 10 & 15 & 15 & 8 & 12 & 11 & 16 & 8 \\
\hline Potentilla anserina & $\mathrm{r}$ & 1 & + & + & 1 & + & + & . & . & 1 & . & . & . & . & . & . & . & . & . & . & . & . \\
\hline Xanthium strumarium & 1 & $\mathrm{r}$ & + & r & + & . & + & + & . & $\mathrm{r}$ & + & . & . & . & . & . & . & . & . & . & . & . \\
\hline Persicaria lapathifolia & $\mathrm{r}$ & $\mathrm{r}$ & . & . & . & . & . & . & . & $\mathrm{r}$ & . & . & . & . & . & . & . & . & . & . & . & . \\
\hline Chenopodium glaucum & . & . & 3 & - & 1 & 1 & + & + & . & - & - & - & + & - & - & + & - & - & - & • & - & - \\
\hline Crypsis aculeata & . & . & b & b & $\mathbf{a}$ & $\mathbf{a}$ & 3 & 1 & $\mathbf{b}$ & b & . & . & . & . & . & . & . & . & . & . & . & . \\
\hline Agrostis stolonifera & . & . & . & . & 1 & . & a & 3 & 1 & 1 & . & . & . & . & . & . & . & . & . & . & . & . \\
\hline Carex secalina & . & . & . & . & . & . & $\mathrm{r}$ & + & $\mathrm{r}$ & . & . & . & . & . & . & . & . & . & . & . & . & . \\
\hline Plantago major ssp. intermedia & . & . & . & . & . & . & + & + & + & . & . & 1 & + & . & . & + & . & . & . & . & . & . \\
\hline Lotus tenuis & . & . & . & . & . & . & 1 & + & + & 1 & . & + & . & . & . & . & . & . & . & . & 1 & . \\
\hline Bidens tripartitus & . & . & . & . & . & . & $\mathrm{a}$ & + & . & + & . & . & . & . & . & . & . & . & . & . & . & . \\
\hline Spergularia salina & . & . & . & . & . & . & . & + & . & 1 & + & $\mathbf{a}$ & a & 1 & . & . & . & . & . & . & . & . \\
\hline Tripleurospermum perforatum & . & . & . & . & . & . & . & . & . & . & . & + & + & + & + & . & + & + & + & . & . & . \\
\hline Polygonum rurivagum & . & . & . & . & . & . & . & . & . & . & . & + & + & + & $\mathrm{a}$ & 1 & $\mathrm{a}$ & $\mathrm{b}$ & 1 & 3 & 3 & 3 \\
\hline Echinochloa crus-galli & . & . & . & . & . & . & . & . & . & . & . & 1 & + & . & a & 1 & 1 & a & a & $\mathrm{r}$ & + & $\mathrm{r}$ \\
\hline Puccinellia distans & . & . & . & . & . & . & . & . & . & a & + & . & 1 & + & 1 & . & . & . & 1 & + & 1 & + \\
\hline Matricaria chamomilla & . & . & . & . & . & . & . & . & . & . & + & . & . & . & . & + & . & $\mathrm{r}$ & . & + & + & . \\
\hline Plantago major & . & . & . & . & . & . & . & . & . & . & . & . & . & . & . & . & 1 & + & + & $\mathrm{r}$ & . & . \\
\hline Potentilla supina & . & . & . & . & . & . & . & . & . & . & . & . & . & . & . & . & $\mathrm{r}$ & . & + & . & + & . \\
\hline Elytrigium repens & . & . & . & . & . & . & . & . & . & . & . & + & . & . & 1 & . & . & . & . & 1 & 1 & + \\
\hline Atriplex tatarica & . & . & . & . & . & . & . & . & . & . & . & . & . & . & . & + & . & . & . & + & . & + \\
\hline Heleochloa schoenoides & 5 & 5 & 1 & b & $\mathbf{a}$ & b & 3 & b & $\mathbf{a}$ & 3 & b & 5 & 3 & 4 & 3 & 4 & 5 & 3 & 3 & $\mathbf{a}$ & $\mathbf{a}$ & $\mathbf{a}$ \\
\hline Atriplex prostrata & + & . & 1 & + & 1 & 1 & 1 & . & + & 1 & . & a & 1 & + & 1 & + & + & . & + & . & + & . \\
\hline Juncus compressus & . & $\mathrm{r}$ & + & + & a & . & $\mathrm{a}$ & $\mathrm{a}$ & $\mathrm{b}$ & $\mathrm{a}$ & . & . & & + & . & . & 1 & + & . & . & + & . \\
\hline Aster tripolium ssp. pannonicus & . & . & . & . & . & 1 & + & $\mathrm{a}$ & $\mathrm{a}$ & 1 & + & . & . & . & . & . & . & . & + & . & . & . \\
\hline
\end{tabular}

* Characteristic species of Cypero-Spergularion salinae Slavnić 1948 are marked in bold.

Species recorded in two relevés only: Artemisia monogyna 1 (20), + (21), Atriplex littoralis + (22), r (23), Bolboschoenus maritimus 2a (4), 1 (13), Cirsium arvense + (12), + (19), Cynodon dactylon + (13), r (21), Hibiscus trionum r (16), r (17), Chenopodium hybridum r (14), r (16), Kochia scoparia 1 (15), + (23), Lepidium ruderale 1 (11), r (15), Plantago tenuiflora 1 (11), 2a (22), Rumex stenophyllus $+(18,19)$, Taraxacum sect. Ruderalia $+(12),+(19)$, Triticum aestivum $\mathrm{r}$ (12), 1 (16). 
Species recorded in one relevé only: Alisma plantago-aquatica $\mathrm{r}$ (13), Amaranthus retroflexus $\mathrm{r}$ (16), Atriplex sagittata 1 (23), Brassica napus + (16), Capsella bursa-pastoris + (16), Datura stramonium + (12), Eleocharis palustris 1 (17), Epilobium tetragonum 1 (17), Hordeum geniculatum + (11), Chenopodium rubrum 1 (13), Chenopodium urbicum + (12), Inula britanica $+(12)$, Juncus bufonius $+(14)$, Lythrum hyssopifolia 1 (17), Pulicaria vulgaris $\mathrm{r}$ (23), Persicaria amphibia 1 (7), Persicaria hydropiper r (17), Rumex crispus + (14), Sclerochloa dura $\mathrm{r}$ (22), Sonchus arvensis $+(7)$, Sonchus asper $+(20)$, Trifolium fragiferum ssp. bonannii $\mathrm{r}(17)$, Trifolium repens $+(23)$.

Localities of relevés (number of relevé, locality, exposition, elevation, altitude, sampling date):

1, 2: Tvrdošovce, denuded bottom of lake near the railway station, $110 \mathrm{~m} \mathrm{n}$. m., 21. 9. 2004, 3-6: Tvrdošovce, denuded waterside of lake, $115 \mathrm{~m} \mathrm{n}$. m., 21. 9. 2004, 3: South, $5^{\circ}$, 4: South-eastern, $3^{\circ}, 5$ : East, $7^{\circ}$, 6: East, $2^{\circ}$. 7-10: 7: Tvrdošovce, denuded waterside of lake near the railway station, East, $3^{\circ}$, 8. 10. 2003, 8: South-eastern, $3^{\circ}$, 8. 10. 2003, 9: East, $6^{\circ}, 115 \mathrm{~m} \mathrm{n.} \mathrm{m.,} \mathrm{21.} \mathrm{9.} \mathrm{2004.} \mathrm{10:} \mathrm{East,} 2^{\circ}$, 8. 10. 2003, 11: Hungary, Hajddúböszórmény, Kispród farmstead, saline pasture near road, $100 \mathrm{~m}$ a. s. 1., 11 . 7. 2007, 12: Močenok, Siky farmstead, depression in cereal field, $130 \mathrm{~m}$ a. s. 1., 5. 10. 2006, 13, 14: Hungary, Solt, dry depression in maize field, $98 \mathrm{~m}$ n. m., 18. 9. 2006. 16: Močenok, Siky farmstead, depression at rural road through a cereal field, $130 \mathrm{~m}$ a. s. 1., 5. 10. 2006., 15. Vel'ké Kosihy, Mostové Nature Reserve (=Dérhidja), slopes on ploughed salt meadow, 115 m n. m., 17. 9. 2006, 17, 19: Močenok, Siky farmstead, depression in lucerne field, 13. 9. 2005, 18: Močenok, Siky farmstead, dry depression in lucerne field, 13. 9. 2005, 20, 22: Vel'ké Kosihy, Mostové Nature Reserve (=Dérhidja), rural road, 115 m a. s. 1., 21. 9. 2004, 21: Vel'ké Kosihy, rural road in ploughed part of Mostové Nature Reserve, $115 \mathrm{~m}$ a. s. 1., 21. 9. 2004.

Tab. 2: Analytic table of the Crypsidetum aculeatae Wenzl 1934 recorded in Hungary

Tabela 2: Analitična tabela asociacije Crypsidetum aculeatae Wenzl 1934 na Madžarskem.

\begin{tabular}{|c|c|c|c|c|c|c|c|}
\hline Relevé number: & 1 & 2 & 3 & 4 & 5 & 6 & 7 \\
\hline Relevé surface $\mathbf{m}^{2}$ & 16 & 16 & 16 & 16 & 16 & 16 & 16 \\
\hline Coverage $\mathrm{E}_{1}(\%)$ & 35 & 40 & 70 & 60 & 85 & 80 & 80 \\
\hline Coverage $\mathrm{E}_{0}(\%)$ & 0 & 0 & 0 & 0 & 0 & 0 & 0 \\
\hline Number of species per relevé & 1 & 1 & 2 & 2 & 2 & 1 & 1 \\
\hline Crypsis aculeata & 3 & 3 & 4 & 4 & 5 & 5 & 5 \\
\hline Puccinellia distans & . & . & + & 1 & . & . & . \\
\hline Bolboschoenus maritimus & . & . & . & . & + & . & . \\
\hline
\end{tabular}

Localities of relevés (number of relevé, locality, exposition, elevation, altitude, sampling date):

1-7: Kiskunság National Park, denuded waterside of the Kelemén-Szék Lake, 92 m a. s. 1., 11. 9. 2007.

Recieved 14. 1. 2008

Revision recieved 31. 3. 2008

Accepted 3. 4. 2008 